\title{
Journal of Mother-Tongue Biblical Hermeneutics and Theology (MOTBIT)
}

ISSN 2676-2838 | Volume 3 Issue 4 - November 2021 pp 77-87 Available online at: https://noyam.org/journals/motbit/ DOI: https://doi.org/10.38159/motbit.2021353

\section{Towards a Language-Based Typology of Church Names in Ghana}

\author{
Osei Yaw Akoto' 1 iD , Juliet Oppong- Asare Ansah² \\ 1 Department of English, Faculty of Social Sciences, College of Humanities and Social Sciences, Kwame Nkrumah University of Science and \\ Technology, Ghana. \\ 2 Department of Language and Communication Sciences, Faculty of Social Sciences, College of Humanities and Social Sciences, Kwame Nkrumah \\ University of Science and Technology, Ghana.
}

\begin{abstract}
Over the years, scholars have sought to provide language-based typologies of names, but while attempts have been made for some sub-branches of onomastics such as anthroponymy and toponymy, there is arguably none for ecclesionymy (the study of church names). Consequently, this paper sought to provide a languagebased typology of the hitherto underexplored area of church names. Data of names of churches in Ghana was built for the present study. Adopting content analysis as the analytical approach, the study realized that church names in Ghana are generally homogenous and heterogeneous linguistically. It was also realized that homogenous/unilingual church names involved English only, Akan only and Ewe only. On the other hand, the heterogeneous church names comprised two types: bilingual and trilingual church names, which contained varied language permutations from the three spheres in Osei Yaw Akoto's classification of languages in Ghana. The paper concludes by making some recommendations for languagein-religion policy in Ghana.
\end{abstract}

Keywords: Church names, Ecclesionymy, Glocal language, Unilingual

(C) 2021 The Author. Published and Maintained by Noyam Publishers.

This is an open access article under the CCBY license (http://creativecommons.org/licenses/by/4.0/)

\section{INTRODUCTION}

One of the things that have engendered the attention of scholars in the field of onomastics is name typology or taxonomy for surnames, ${ }^{1}$ nicknames, ${ }^{2}$ place names ${ }^{3}$ and names of teams,${ }^{4}$ etc. Typologies in names are provided for convenience, identification, and some kind of ideological labelling. It also reveals crucial information about the naming practices of a particular sociocultural group. ${ }^{5}$ These typologies are provided from different

1 David. H. Parkin, \& Harry Parkin. Surname Typology and the Problem of Inconsistent Classification. Names 61(4). (2013): 200-211.

2 Alvydas, Butkus. An Outline and Classification of Lithuanian Nicknames. Names 47(2). (1999):125-138.

3 Jan, Tent \& David, Blair. Motivations for Naming: The Development of a Toponymic Typology for Australian Place Names. Names 59(2). (2011): 67-89.

4 Ezra, Zeitler. J. A. Taxonomy of Secondary School Athletic Team Names and Mascots in the United States. Names 66(4). (2018): 219-232.

5 Kofi, Agyekum. The Sociolinguistics of Akan Personal Names. Nordic Journal of African Studies 15(2). (2006): 206-235; Kwasi, Ansu-Kyeremeh. Communicating Nominatim: Some Social Aspects of Bono Personal Names. Research Review 16(2). (2000): 19-33; Abraham, K Bisilki. A Study of Personal Names among the Bikpakpaam (the Konkomba) of Ghana: The Linguistics, Typology and Paradigm Shifts. Language Sciences 66. (2018): 15-27. 
points of view: semantic, pragmatic, sociolinguistic, ideological, political, religious, linguistic, and syntactic. ${ }^{6}$ One of the name-kinds that somewhat received some typology is the names of churches. ${ }^{7}$ Zelinsky $^{8}$ classified church names based on the generics such as 'ministry', 'church', 'mission' and 'cathedral', but Noreen did so based on what he termed 'denominational orientation'. 'The present study, therefore, appears to be the first systematic and comprehensive language-based classification of church names. Such a classification is crucial as it offers another lens to appreciate the interface between language and religion in general, and Christianity in particular.

Compared to other name-kinds for persons, places, companies, animals and streets, ${ }^{10}$ church names remain "onomastic terra incognita". ${ }^{11}$ After Fairclough's ${ }^{12}$ seminal paper, a few studies have been undertaken. ${ }^{13}$ All the aforementioned studies, contra $\mathrm{Pan}^{14}$, are based in the American context. Those studies generally reveal the peculiarities of church names in America. It is, therefore, important for studies to be conducted across the globe on church names to reveal how geographical, cultural and linguistic contexts inform the naming of churches. Thus, the present study provides a classification of churches in Ghana, given the country's multilingual and multicultural peculiarities. ${ }^{15}$ Downey contends that the significance of the name of a church is not only realized in its history, theology or meaning but also the embedded language, hence, the present study, which provides a language-based classification of church names. ${ }^{16}$

\section{DATA SOURCE AND PROCEDURE OF ANALYSIS}

The names of the denominations in the "churchdom"17 in Ghana constituted the data for the present study. The study is part of a general ongoing research that seeks to explore various aspects, ranging from theology to linguistics (pragmatics, semantics, grammar, sociolinguistics), of church names in the Ghanaian religious landscape. In all, thousand two hundred and sixty-seven (1267) churches constituted the data for the present study. The church names were gathered from multiple sources including billboards, posters, signages, souvenirs, online (the websites of christen church associations such as Ghana Pentecostal and Charismatic Council, Ghana Christian Council, etc.), as multi-source of gathering data is said to be characteristic of church

6 John, Anderson. On the Structure of Names. Folia Linguistica 37(3-4). (2003): 347-398; John, M. Anderson. The grammar of names. (Oxford: Oxford University Press. 2007); Willy, Van Langendonck. Theory and Typology of Proper Names (Vol. 168) (Berlin: Walter de Gruyter 2008).

7 Thomas, G. Fairclough, "New Light" on "Old Zion": A Study of the Names of White and Negro Baptist Churches in New Orleans. Names 8(2). (1960):75-86; Robert. G. Noreen. Ghetto Worship: A Study of the Names of Chicago Storefront Churches. Names 13(1). 1965): 19-38; Wilbur, Zelinsky. The Names of Chicago's Churches: A Tale of at Least Two Cultures Names 50(2). (2002): 83-103.

8 Zelinsky, The Names of Chicago's Churches: A Tale of at Least Two Cultures. 83-103.

9 Ghetto Worship: A Study of the Names of Chicago Storefront Churches. 19-38.

${ }^{10}$ Oliviu. Felecan \& Alina, Bughesiu. (Eds.). Onomastics in Contemporary Public Space. (Cambridge: Cambridge Scholars Publishing. 2013); Carole, Hough \& Daria, Izdebska. (Eds.). The Oxford Handbook of Names and Naming. (Oxford: Oxford University Press. 2016); Tent. \& Blair. Motivations for Naming: The Development of a Toponymic Typology for Australian Place Names, 67-89.

11 Fairclough, "New light" on "Old Zion": A Study of the Names of White and Negro Baptist Churches in New Orleans. 75-86.

12 Fairclough. "New light" on "Old Zion": A Study of the Names of White and Negro Baptist Churches in New Orleans. 75-86.

${ }^{13}$ Hanting, Pan. The Immigration of Key Cultural Icons: A Case Study of Church Name Translation in Macao. (In. K. Malmkjær, A. Şerban and F. Louwagie (Eds.). Key Cultural Texts in Translation (pp.140-185). (Amsterdam: John Benjamins Publishing Company. 2018); James, B. Stronks. Names of Store-Front Churches in Chicago. Names 10(3). (1962): 203-205; James, B. Stronks. New Store-Front Churches in Chicago. Names 11(2). (1963):136; James, B. Stronks. Chicago Store-Front Churches Names 12(2). (1964): 127-129; Rogers P. Burwell. Naming Protestant Churches in America. Names 11(1). (1963): 44-51; Charles, A. Ferguson. Saints Names in American Lutheran Church Dedications. Names 14(2). (1966): 76-82; Roger, W. Stump. Pluralism in the American Place-Name Cover: Ethnic Variations in Catholic Church Names. North American Culture 2. (1986): 126-140; Roger, W. Stump. Church-Naming Practices among Eastern Rite Catholics in the United States. Names: Journal of Onomastics 36(1). (1988): 85-90; Zelinsky. The Names of Chicago's Churches: A Tale of at Least Two Cultures. 83-103.

14 Pan. The Immigration of Key Cultural Icons: A Case Study of Church Name Translation in Macao. 140-185.

15 Solace, A. Yankson, Language Contact and Change in Linguistically Heterogeneous Urban Communities: The Case of Akan in Accra.

${ }^{16}$ Glanville, Downey. The Name of the Church of St. Sophia in Constantinople. Harvard Theological Review 52(1). (1959): 37-41.

17 Zelinsky. The Names of Chicago's Churches: A Tale of at Least Two Cultures. 83-103. 
names studies. ${ }^{18}$ The multi-source method for the collection of the data was necessitated by the absence of a registry or directory for all churches in Ghana. The authors were, therefore, pragmatic in the data collection by adopting a collect-as-you-go approach. As they travelled across the then ten regions (now sixteen) in Ghana, for social, religious and academic purposes, for a ten-year span (2009-2019), they recorded all church names they saw from various sources such as souvenirs, billboards, brochures, etc.

The authors read the data to identify the various languages employed in them, and developed codes for the various languages identified. In all, nine (9) individual languages were identified in the church names. Drawing on Akoto's ${ }^{19}$ typology of languages, the authors classified the identified languages into global, local and glocal. The global ones comprise all languages that are not indigenous Ghanaian languages, excluding English which Akoto describes as 'glocal'. It was easy to identify the English and Akan language-medium church names, given their advanced competence in them. For the global languages (i.e. Greek, Latin, Hebrew/ Aramaic, and Yuroba) and the other local languages, different strategies were employed. For the local languages, the authors contacted a lecturer in the Department of Language and Communication Sciences in Kwame Nkrumah University of Science and Technology, Ghana who knows a number of the local languages to guide the authors in identifying the languages employed in the church names. This is in line with Pearce ${ }^{20}$ who recounts that this approach is part of the methodology in analyzing multilingual names. On the other hand, for the global languages, there were some expressions which were readily known (e.g. Rhema, Logos) but those not known, Google translate was used to help in identifying the languages. A general Google search was conducted for some of the words in certain cases such as 'Aladura Church'. 'Aladura' is a Yuroba word meaning the praying people or the owners of prayer. ${ }^{21}$

After identifying the languages, the authors classified the church names based on the number of languages employed in them. A linguistically homogeneous church name was labelled ' $U$ ' for unilingual, while those with two languages were labelled ' $\mathrm{B}$ ' for Bilingual, and ' $\mathrm{T}$ ' for trilingual ones. In terms of the degree of multilingualism, the highest church names identified were trilingual.

\section{RESULTS AND DISCUSSION}

This section discusses the indispensable issues that came out when data was analyzed.

\section{Classifications of church names}

Some church names were found to be linguistically homogeneous and others heterogeneous. These are discussed under unilingual and multilingual church names (ecclesionyms) in the ensuing sections.

\section{Unilingual Ecclesionyms}

Unilingual church names are linguistically homogeneous (i.e. comprising one language only). Table 1 shows that three types of this church name-kind were identified in the data: English only, Akan only, and Ewe only -both labelled as mother tongue ecclesionyms. Guihang and Bingjie ${ }^{22}$ argue that language choice has commercial, branding, promotional and marketing purposes. Churches that project their identities through linguistic homogeneity seek largely to associate themselves with the wholeness of the chosen languages.

\footnotetext{
${ }_{18}$ Noreen. Ghetto Worship: A Study of the Names of Chicago Storefront Churches, 19-38; Zelinsky. The Names of Chicago's Churches: A Tale of at Least Two Cultures. 83-103.

19 Osei, Y. Akoto, Language Choice and Institutional Identity: A Study of the Mottos of Ghanaian Educational Institutions. WORD 64(3). (2018):177-190.

20 Thomas, M. Pearce. Name Patterns in Aelfric's Catholic Homilies. Names 14(3). (1966):150-156.

${ }^{21}$ Akindolie, Akinwumi. Aladura Churches as Agents of Social Transformation in South-West Nigeria. In African Initiated Christianity and the Decolonisation of Development. (Pp.164-174). (New York: Routledge, 2020).

22 Guo, Guihang \& Li, Bingjie. Linguistic Landscape of China: A Case Study of the Language Use of Shop Signs in Wuhan. Studies in Literature and Language 15(1). (2017): 1-9.
} 
Table 1: Unilingual church names in Ghana

\begin{tabular}{llll}
\hline S/N & Unilingual church names & Frequency & Percentage \\
\hline English Only & 1018 & 99.51 \\
Akan Only & 3 & 0.29 \\
Ewe Only & 2 & 0.20 \\
TOTAL & 1023 & 100
\end{tabular}

The ensuing subsections discuss the two broad identified church names: English only, and mother-tongue (comprising Akan only, and Ewe only).

\section{English-only Ecclesionyms}

It is shown in Table 1 that unilingual church names in Ghana are markedly English-medium, as it constitutes approximately 97\%. Some of these churches are 'Abiding Faith Church International', 'Body of Christ Revival International Ministry', 'Charismatic Evangelistic Ministry', 'Divine Healers Prayer Ministry', and 'Divine Love Chapel International'. The dominance of English-medium names is not surprising given that Christianity was introduced in Ghana by the English-speaking people. The pioneering churches with European origins were English-medium and this greatly influenced the naming of African-initiated/independent/indigenous/ instituted churches in Ghana. Besides, as noted by Eclipse and Tenedero, ${ }^{23}$ English's dominance reflects and affirms its increasing impact as the language of globalization, and the Englishization of discourses across the globe. ${ }^{24}$

Akoto $^{25}$ describes English in Ghana as a glocal language, given its long-standing association with the Ghanaian sociolinguistic and cultural context. Ghanaians generally identified themselves with the English language. In fact, a significant number of Ghanaians have either passive or active knowledge of the English Language. Ghanaians' attitude towards English project it as a linguistic summum bonum, which seems to define an individual by designating an enviable language-oriented ethos to the users. Consequently, English medium church names are likely to attract a larger following given 'glories' and ideologies surrounding it as the language of enlightenment, and development.

Politics has permeated almost all facets of life in Ghana, and language is no exception. The English language serves as a 'social differentiator' ${ }^{26}$ in Ghana, in particular, and the globe at large. An all-local language-medium or bilingual church name can be considered ethnocentric thereby engaging in a kind of 'us and them' polarity regarding language use for ecclesionymic references. An all-English medium name is considered a unifying one given its ethnolinguistic neutral status. An English-only name arguably enjoys a greater acceptance across ethnic groups than a mother-tongue medium one. Dseagu ${ }^{27}$ contends that English as 'an imperial and colonial language of conquest and domination has been transformed into a national language acceptable and accessible to all sections of the nation and identified with peace, progress and development'. The 'peace, progress and development' transcend the physical to encapsulate the soul and the spirit as well. It is thus important to note that the English language resonates with the 'spirit' of most Ghanaian Christians, especially the teeming youth, rather than their local languages. Consequently, aside from the church names in English, English-medium church services, in recent times, have proliferated in Ghana. In fact, some churches that have 'International Worship Center' branches that use only the English language for all their church activities and programmes.

\footnotetext{
23 Abigail, N. Eclipse \& Patricia. P. Tenedero. The linguistic landscape of Manila Central Post Office: a macro-linguistic analysis. Asian Journal of English Language Studies (AJELS) 6. (2018): 157-176.

${ }^{24}$ Eclipse \& Tenedero. The linguistic landscape of Manila Central Post Office: a macro-linguistic analysis. 157-176.

25 Akoto, Language choice and institutional identity: a study of the mottos of Ghanaian educational institutions, 177-190.

26 William, Labov. The Social Stratification of (r) in New York City Department Stores. (In Dialect and Language Variation (304329). Academic Press. 1986)

27 Samuel, A. Dseagu. English in Ghana. English Studies in Africa 39(1). (1996): 57-66.
} 


\section{Mother-tongue Ecclesionymy}

The data revealed that only two Ghanaian languages were homogeneously employed in church names. And as shown in Table 1 with minimal occurrences (i.e. 0.49\%). This is evidence of English's hegemony over the local languages. These languages are Akan and Ewe, hence Akan only and Ewe only church names. The practice of using local languages only in the church is referred to as mother-tongue ecclesionymy. The mother tongue only church names are evidence of the language dynamics in the religio-linguistic landscape in Ghana. It was found that in the mother tongue-medium church names, the names were translated bilingually from English to an Akan/Ewe, and vice versa as in "The True Worshippers' Church (Nokware Asorefo Asore)" and "Apostoiowo Pe Dedefia Habobo (Apostolic Revelation Society)". These were found in the 'official' names of the churches in official communications. The local language-medium church names suggest an evolution of the so-called 'sacred' languages to vernacular languages such as Akan and Ewe for church naming purposes. Similarly, Coluzzi and $\mathrm{Kitade}^{28}$ also found local languages in the Christian LL in Malaysia, while $\operatorname{Pan}^{29}$ reported that the English-medium church names in China were translated into Chinese. Sawyer ${ }^{30}$ attests the use of local languages in church names became prevalent after the reformation when Protestantism became widespread.

Church names ideologically and theologically define the members in a particularly Christian denomination. ${ }^{31}$ Thus, the use of the mother tongue in the church names is crucial as Kuwornu-Adjaottor ${ }^{32}$ contends that "a mother-tongue is a repository of indigenous wisdom, knowledge, insight, science, theology and philosophy". The local languages in church names allow Ghanaians to Christine their 'church' based on their own worldviews which are inextricably part of their linguistic heritage. ${ }^{33}$ Africans in general and Ghanaians, in particular, have sought to de-westernize Christianity by introducing local flavours in the form of language, and performances such as drumming and dance. ${ }^{34}$ The use of the local languages in the church names can, therefore, be regarded as one of the attempts to indigenize Christianity to make the churches resonate with the Ghanaian sociolinguistic and cultural context. ${ }^{35}$ The Ghanaian-language-only churches demonstrate an emerging 'protest' against the 'foreign language orthodoxy' in church naming in Ghana. This seeks to empower the local languages in order to increase their functional loads in written ecclesiastical discourses.

Yevudey and $\mathrm{Agbozo}^{36}$ classify languages in Ghana into ex-colonial, dominant and minority languages. The Ghanaian languages homogeneously employed in the church names are part of the eleven dominant or 'majority' local languages that are taught as subjects and used as a medium of instruction. They are part of the first four dominant local languages. ${ }^{37}$ In Ghana, local languages in Christendom are employed largely for sermons, songs, and Bible translation purposes. In terms of ecclesiastical titles such as bishop, pastor,

${ }^{28}$ Paolo, Coluzzi \& Rie, Kitade. The Languages of Places of Worship in the Kuala Lumpur Area: A Study on the "religious" linguistic landscape in Malaysia. Linguistic landscape 1(3). (2015): 243-267.

${ }^{29}$ Hanting, Pan. The Immigration of Key Cultural Icons: A Case Study of Church Name Translation in Macao. (In. K. Malmkjær, A. Şerban and F. Louwagie (Eds.). Key Cultural Texts in Translation (pp.140-185). (Amsterdam: John Benjamins Publishing Company. 2018).

30 John, Sawyer. Christianity in Europe. In JFA Sawyer, JMY Simpson (eds.). Concise Encyclopedia of Language and Religion. 33-35. (Oxford: Elsevier. 2001).

${ }^{31}$ Pan. The Immigration of Key Cultural Icons: A Case Study of Church Name Translation in Macao; Jean, Paul Kouega. Language Management in "International” Pentecostal Churches in Cameroon. Open Access Library Journal 5(5). (2018): 1-15; Jan, Tent. Indigenous Toponyms in the Antipodes: A Gazetteer-Based Study. Names, 65(4). (2017): 204-214; Zelinsky. The Names of Chicago's Churches: A Tale of at Least Two Cultures, 83-103.

32 Jonathan, E. T. Kuwornu-Adjaottor. Mother-Tongue Biblical Hermeneutics: A Current Trend in Biblical Studies in Ghana. Journal of Emerging Trends in Educational Research and Policy Studies 3(4). (2012): 575-579.

33 Kuwornu-Adjaottor. Mother-Tongue Biblical Hermeneutics: A Current Trend in Biblical Studies in Ghana. 575-579.

34 Alfred, Koduah. Christianity in Ghana Today. (Accra: Advocate Publishing. 2004).

${ }^{35}$ Teresa, Zimmerman-Liu \& Teresa, Wright. What is in a Name? A Comparison of Being Branded a Religious Cult in the United States and the People's Republic of China: Witness Lee and the Local Churches. Journal of Church and State 60(2) (2015): 187-207.

${ }^{36}$ Elvis, Yevudey \& Edzordzi, G. Agbozo. Teacher Trainee Sociolinguistic Backgrounds and Attitudes to Language-In-Education Policy in Ghana: A Preliminary Survey. Current Issues in Language Planning 20(4). (2019): 338-364.

37 Yankson, Language Contact and Change in Linguistically Heterogeneous Urban Communities: The Case of Akan in Accra. (724) 
archbishop, cardinal, etc., and naming of Christian facilities and artefacts, the most preferred language had been English. Regarding the naming of churches as organizations, it has been perceived to be the preserve of the English Language. To find local language only church names in Ghana appears to be an evolving phenomenon. It can thus be described as a kind of linguistic diffusion. ${ }^{38}$ where one observes the use of local languages moving from the 'domains' of higher usage (such as face-to-face conversation) to the hitherto occluded domains such as church naming. Moreover, it can be argued that the rights of the local languages are beginning to be recognized for ecclesionymic purposes. The authors were thus convinced that the local languages with their socio-naturalistic powers, and persuasive force can be adopted for church naming and may even serve greater purposes more than what the church namers anticipated.

In the Ghanaian linguistic landscape in the 21 st century, the mediatization of the local languages has increased their competitiveness in the business, entertainment, and most importantly the religious sector. ${ }^{39}$ This emerging reality largely challenges the Matthew effect phenomenon applied in sociolinguistic studies, which supports the widening of the gap in favour of the dominant language. ${ }^{40}$ Consequently, the use of the local languages in church names suggests that the local languages are gradually narrowing the gap of English coverage in Ghana.

Historically, the English language enjoyed some kind of monopoly in the naming of churches in the early days of the introduction of Christianity in Ghana. ${ }^{41}$ However, this monopoly is gradually being challenged as the local languages, although representing just 0.49 , are beginning to share this discourse responsibility/ right with the English language. The emergence of mother tongue-medium church names may be attributed to the lack of proficiency in English on the part of the founders of the churches. However, this view can be quickly refuted such that some founders of some megachurches in Ghana who are known to have little or no formal education have English-medium church names. Again, it is known that in some cases the name of the churches did not originate from the founders. For example, "The Church of Pentecost" is recorded to have had its name through prophecy by one Apostle George Alfonso Woode. ${ }^{42}$ Moreover, the local languages are chosen largely to give ethnolinguistic flavour to such churches to make them appealing to the local speech communities. In this regard, members may have a natural flair of owning such churches given that they are named in their own languages.

It may, therefore, be argued that proselytizing or evangelizing may be facilitated or enhanced through "familiar language." ${ }^{43}$ Arguably, the local language-medium church names may have greater recognition and acceptance by the teeming uneducated population than the English-medium named churches. This may even explain the existence of English-to-local language church names, a 'nativizing' strategy believed to increase the local folks' acceptance of the church. The use of the local languages in the church names may even have some doctrinal and theological implications, as Kuwornu-Adjaottor contends: "A mother-tongue is a repository of indigenous wisdom, knowledge, insight, science, theology and philosophy". ${ }^{44}$ It may be used for socio-rhetorical purposes to persuade the communities that the God of our church speaks your language, and that He is not an "unknown God" (See Acts 17: 23 of the King James Version of the Bible). ${ }^{45}$ On the other hand, even if the Christian God remains unknown to the people, communicating discourses on and about him such as church name in the local languages seems to draw Him closer to the people, in a kind of maxim, the unknown God in a known language. Just as some scholars are advocating mother tongue-medium education ${ }^{46}$

\footnotetext{
${ }^{38}$ Bates, L. Hoffer. Language borrowing and language diffusion: an overview. Intercultural Communication Studies 11(4) (2002): 1-37; Samuel, G. Obeng. An analysis of the linguistic situation in Ghana. African Languages and Cultures 10(1). (1997): 63-81.

39 Obeng. An Analysis of the Linguistic Situation in Ghana. 63-81; Yankson, Language Contact and Change in Linguistically Heterogeneous Urban Communities: The case of Akan in Accra. (Pp. 7-24).

${ }^{40}$ Matthew, A. Lamb, Effect of English Language Education in Developing Country Context. In H Coleman (ed.). Dreams And Realities, Develop Countries and the English Language (pp. 186-206). (London: The British Council. 2011).

41 Koduah. Christianity in Ghana Today.

42 Benjamin, Ali. Prophetism in the Church of Pentecost in Ghana. (Accra: Advent Press. 2015).

${ }^{43}$ Charles, Owu-Ewie. Language, Education and Linguistic Human Rights in Ghana. Legon Journal of the Humanities 28(2). (2017):151-172.

${ }^{44}$ Kuwornu-Adjaottor. Mother-Tongue Biblical Hermeneutics: A Current Trend in Biblical Studies in Ghana, 575-579.

45 King James Version of the Bible.

46 Owu-Ewie. Language, Education and Linguistic Human Rights in Ghana. 151-172.
} 
and hermeneutics in Ghana, the 'owners' or names of such churches are also probably arguing for mothertongue ecclesionymy in order to meet the religio-linguistic needs of the people. ${ }^{47}$

Nonetheless, the mother tongue-medium ecclesionyms may suffer some disadvantages. One, there may be some ethnic sentiments associated with the languages as some people unwilling to cede their ethnolinguistic rights may decide not to accept and welcome such churches. This view is echoed by Dseagu: ${ }^{48}$ "Akan could have been officially used as a common language but for the fact that, it being the language of the Asante, speakers of the other languages would resent what they would have perceived as a modern version of the age-old Asante domination". Besides, the use of the local language may also be a barrier to the global spread of the church since the other nationals may not understand the adopted languages in the names of the churches. It is likely that such churches may adopt a global language when they begin to operate beyond the shores of Ghana.

\section{Multilingual church names}

Multilingualism in linguistic landscape research can be described as translational or non-translational, which may correspond with code-switching and code mixing. ${ }^{49}$ The two forms correlate with the principles: same message, different languages, and different messages, different languages respectively. There were six instances of translational multilingualism, where the church names were translated from either a local language to English as in "Apostoiowo Pe Dedefia Habobo (Apostolic Revelation Society)", or from English to a local language such as "The True Worshippers' Church (Nokware Asorefo Asore)". However, in the non-translational type, different languages are mixed in the church names as in "Aseda Baptist Church", and "Phanerosis Prayer Network International". The first contains Akan and English, while the second has Greek and English. In this paper, the focus is on non-translational multilingualism, which involves bilingual and trilingual ecclesionyms (church names).

\section{Bilingual Ecclesionyms}

One subtype of multilingual church names is the bilingual type, which involves two languages. As shown in Table 2, the bilingual church names have different language combinatorics - as many as eight (8).

Table 2: Bilingual church names in Ghana

\begin{tabular}{llll}
\hline S/N & Bilingual church names & Frequency & Percentage \\
\hline 1. & English-Akan & 16 & 12.3 \\
2. & English-Hebrew & 81 & 62.9 \\
3. & English-Greek & 26 & 20.0 \\
4. & English-Sanskrit & 1 & 0.7 \\
5. & English-Ga & 3 & 2.3 \\
6. & Hebrew-Akan & 1 & 0.7 \\
7. & Latin-English & 1 & 0.7 \\
8. & Yuroba-English & 1 & 0.7 \\
& TOTAL & $\mathbf{1 3 0}$ & \\
\hline
\end{tabular}

Drawing on Akoto's classification of languages into global, glocal and local, the authors subcategorized the bilingual church names into global-local (e.g. Hebrew-Akan); glocal-local (e.g. English-Ga), global-glocal (Greek-English). No church name was found with global-global and local-local language blends. On the former, given that the identified global languages in the church names are not spoken in Ghana, a blend of the two will reduce the degree of its attractiveness since people may struggle to understand the 'logos' and the 'rhema' of such church names. Regarding the local-local, it is difficult for reasons to be adduced for its

47 Daniel, N. A. Aryeh. Inductive Biblical Interpretation and Mother-Tongue Biblical Hermeneutics: A Proposal for Pentecostal/ Charismatic Ministries in Ghana Today. The Journal of Inductive Biblical Studies 3(2). (2016): 6; Kuwornu-Adjaottor. Mother tongue biblical hermeneutics: a current trend in biblical studies in Ghana, 575-579.

48 Dseagu. English in Ghana. English Studies in Africa 39(1). (1996): 57-66.

49 Obeng. An analysis of the linguistic situation in Ghana. 63-81. 
absence given that such blends are common in Christian songs in Ghana.

The mixed churches particularly those with local language-present probably seek to establish dual identities as churches of Ghana and the world. ${ }^{50}$ These linguistically heterogeneous church names position themselves in the worlds of the blended languages. In addition, such churches concurrently associate themselves with the glories (past and present), ideologies, and even theologies associated with the employed languages. The degree of local presence in a glocal-local ecclesionym is greater than the global-local ones. In the glocallocal, the 'localness' is felt twice (i.e. in the English and the Ghanaian indigenous languages employed). For example, the church "Apam Prayer Camp" which contains English and Akan can be said to have a higher degree of Ghanaian flavor than "Adonai Daada Kwasiada Awurade Kasa Mpaebo" which contains Hebrew (i.e. Adonai), which is a language unknown to most Ghanaians, and Akan (i.e. Daada Kwasiada Awurade Kasa Mpaebo).

\section{Trilingual Ecclesionyms}

The second subtype of multilingual church names involves three languages, hence trilingual church names. Under this subtype, the authors identify only two different language permutations, as shown in Table 3.

Table 3: Trilingual church names in Ghana

\begin{tabular}{llll}
\hline S/N & Trilingual church names & Frequency & Percentage \\
\hline 1. & Akan + Hebrew + English & 2 & 66.67 \\
2. & Hebrew + Ga + English & 1 & 33.33 \\
& TOTAL & 3 & \\
\hline
\end{tabular}

In these churches, there are languages that represent the three spheres in Akoto's ${ }^{51}$ model. In the Akan + Hebrew + English church name, Akan, Hebrew and English are adopted from the local, global and glocal spheres respectively. These churches arguably can be said to promote the pluralist, rather than exclusivist or inclusivist, view on language choice. More so, they can be said to align themselves towards a kind of linguistic utilitarianism whereby choices are made to ensure representativeness. The trilingual-ecclesionymic churches relatively support linguistic democracy and rights than the unilingual and bilingual ones. At least, based on the languages selected in the names, the churches present themselves as "all-languages and people" churches, resonating Revelation 7: 9 (NIV):

After this I looked, and there before me was a great multitude that no one could count, from every nation, tribe, people and language, standing before the throne and before the Lamb. They were wearing white robes and were holding palm branches in their hands (emphasis mine).

The church namers probably seek to combine the characteristics in terms of past, present and future of the languages in order to present a church 'self' positioned in the global, glocal and the local spheres. Such church names may arguably appeal to a greater number of people from varied ethnolinguistic backgrounds. For example, the church name "Bethel Kwabenyo Prayer Ministry" has "Bethel" from Hebrew, "Kwabenyo" from Ga and "Prayer Ministry" from English. Arguably, all the languages are represented in the name, and thus the people of such languages may find themselves linguistically represented. The churches thus enact trilingual identities largely associated with the glories of the chosen languages. Seeman asserts that "identity, though complex, can be encoded in a name" through, among other things, the language source of the name. ${ }^{52}$ In these names, the churches construct global, glocal and glocal identities ${ }^{53}$. Multiple languages in cases like these are employed as mobilization strategies in order to increase one's acceptance in the communities where the chosen languages are used. ${ }^{54}$

\footnotetext{
50 Akoto. Language Choice and Institutional Identity: A Study of the Mottos of Ghanaian Educational Institutions, 177-190.

51 Akoto. Language Choice and Institutional Identity: A Study of the Mottos of Ghanaian Educational Institutions, 177-190.

52 Mary, V. Seaman. Name and identity. Canadian Journal of Psychiatry 25(2). (1980): 129-137.

53 Akoto. Language choice and institutional identity: a study of the mottos of Ghanaian educational institutions. 177-190.

${ }^{54}$ Guihang \& Bingjie. Linguistic landscape of China: a case study of the language use of shop signs in Wuhan,1-9.
} 


\section{RECOMMENDATION}

Several countries across the globe are advocating Mother-Tongue-Based Multilingual Education (MTBMTE), which of course does not account for the naming of the religious institutions. Based on this course, the following recommendations are made below.

1. A more nuanced policy can be enacted in religion for the local languages to be employed in naming religious institutions. This law may advocate for what the authors termed translational, or nontranslational forms, whereby the church name in English may officially have its local language version, or the English language and the local languages may be mixed respectively.

2. Further studies may adopt an ethnographically-oriented approach where church 'namers' may be interviewed to ascertain why they chose the languages in their church names.

\section{CONCLUSION}

The study showed that the church names in Ghana are broadly homogeneous and heterogeneous linguistically, which are termed unilingual and multilingual respectively. The unilingual church name type involved glocal language (i.e. English) and local language (i.e. mother tongue ecclesionyms). ${ }^{55}$ The mother tongue ecclesionym reveals the extent to which the local linguistic 'flavour' has been introduced into the naming practices of churches in the Ghanaian Christendom. Akan and Ewe were the two mother tongues identified to be homogenously employed in the naming of churches in Ghana. Unsurprisingly, Akan is considered the local lingua franca, hence, lingua ecclesia, in Ghana such that it appears that the language seems to travel with Christianity. For example, The Church of Pentecost, the leading Christian denomination in Ghana has over a thousand full time ministers. ${ }^{56}$ These ministers, although come from varied ethnolinguistic backgrounds, have active knowledge in Akan. It appears that one's competence in Akan is one of the criteria for 'calling' people into full time ministry in the church. On the other hand, the fact that Ewe is considered among the four dominant languages in Ghana also justified its homogeneous use in church names. Aside from the unilingual church names, the research also identified bilingual and trilingual ones. The multilingual church names had different language combinatorics as shown in Table 2. Drawing on Akoto's ${ }^{57}$ typology of languages Ghana, it was discovered that there were global-local language, glocal-local language, global-glocal language permutations. These language permutations project multiple identities of the church and further reveal the language-based ideologies of such Christian denominations or bodies.

The findings support the intertwined relations between language and religion in general, and Christianity in particular. In addition, in recent times people have explored the role of mother tongues in biblical studies, specifically biblical exegesis and hermeneutics. ${ }^{58}$ The paper has shown that an occluded branch of ecclesiology, which is ecclesionymy, the naming of churches, is also an area for inclusion of mother tongues in church related discourses. Finally, the finding regarding the dominance of English in the church names suggests the need for government to enact laws to regulate language-in-religion, as done in education across the globe.

\section{ABOUT AUTHORS}

Osei Yaw Akoto (PhD) is a lecturer in the Department of English, Faculty of Social Sciences, College of Humanities and Social Sciences, Kwame Nkrumah University of Science and Technology, Ghana. He holds B.A (Hons) in English Language and Philosophy; M.Phil. and $\mathrm{PhD}$ in English Language, all from the University of Cape Coast, Cape Coast, Ghana. He teaches courses like English for Academic Purposes, Sociolinguistics, Discourse Studies and Error Analysis. His research interest include Linguistic Landscape, Onomastics, Corpus Linguistics and Academic Discourse. His recent publication appeared in Word.

\footnotetext{
55 Akoto. Language choice and institutional identity: a study of the mottos of Ghanaian educational institutions, 177-190.

${ }^{56}$ Samuel, B. Adubofuor. \& Seth, O. Asare. Badu. Fulfilling the great commission through the "house church": a case study of home cells of the Church of Pentecost. E-Journal of Religion and Theological Studies 5(2). (2019): 78-91.

57 Akoto. Language choice and institutional identity: a study of the mottos of Ghanaian educational institutions. 177-190.

${ }^{58}$ Kuwornu-Adjaottor. Mother-tongue biblical hermeneutics: a current trend in biblical studies in Ghana, 575-579.
} 
Juliet Oppong-Asare Ansah is a lecturer in the Department of Language and Communication Sciences, Faculty of Social Sciences, College of Humanities and Social Sciences, Kwame Nkrumah University of Science and Technology, Ghana. She holds Bachelor of Education in Psychology and Master of Philosophy in Ghanaian Language (both from the University of Cape Coast, Cape Coast Ghana). Currently, she is a PhD candidate in Linguistics at the University of Ghana, Legon, Accra-Ghana. She has been teaching courses like Semantics, Aesthetics of Oral Literature, Translation, Creative Writing, Pragmatics and Akan Written Expression. Her research interest include Ethnographic Linguistics, Diachronic Studies, Semantics and its interfaces, Language Contact and Translation Studies.

\section{BIBLIOGRAPHY}

Adubofuor, Samuel. B. \& Badu, Seth. Asare. O. Fulfilling the Great Commission through the "House Church": a Case Study of Home Cells of the Church of Pentecost. E-Journal of Religion and Theological Studies 5 no. 2, (2019):78-91.

Agyekum, Kofi. The Sociolinguistic of Akan personal names. Nordic Journal of African Studies 15 no2, (2006): 206-235.

Akoto, Osei. Y. Language Choice and Institutional Identity: A study of the Mottos of Ghanaian educational Institutions. WORD 64 no. 3, (2018): 177-190.

Ali, Benjamin. Prophetism in the Church of Pentecost in Ghana. (Accra: Advent Press. 2015).

Anderson, John. M. The Grammar of Names. Oxford: (Oxford University Press. 2007).

Anderson, John. On the Structure of Names. Folia Linguistica 37 no. 3-4, (2003): 347-398.

Ansu-Kyeremeh, Kwasi. Communicating Nominatim: Some Social Aspects of Bono personal names. Research Review 16 no. 2, (2000): 19-33.

Aryeh, Daniel. Nii. A. Inductive Biblical Interpretation and Mother-Tongue Biblical Hermeneutics: A Proposal for Pentecostal/Charismatic Ministries in Ghana Today. The Journal of Inductive Biblical Studies 3 no. 2, (2016): 6.

Bisilki, Abraham. K. A Study of Personal Names among the Bikpakpaam (the Konkomba) of Ghana: the Linguistics, Typology and Paradigm Shifts. Language Sciences 66, (2018): 15-27.

Butkus, Alvydas. An Outline and Classification of Lithuanian Nicknames. Names 47 no. 2, (199: 125-138.

Coluzzi, Paolo. \& Kitade, Rie. The Languages of Places of Worship in the Kuala Lumpur Area: A Study on the "Religious" Linguistic Landscape in Malaysia. Linguistic Landscape 1 no.3, (2015): 243-267.

Downey, Glanville. The Name of the Church of St. Sophia in Constantinople. Harvard Theological Review 52 no 1, (1959): 37-41.

Dseagu, Samuel. A. English in Ghana. English Studies in Africa 39 no. 1, (1996): 57-66.

Eclipse, Abigail. N., \& Tenedero, Pia. Patricia. P. The Linguistic Landscape of Manila Central Post Office: A Macro-Linguistic Analysis. Asian Journal of English Language Studies (AJELS) 6, (2018): 157-176.

Fairclough, Thomas. G "New light" on "Old Zion": A Study of the Names of White and Negro Baptist Churches in New Orleans. Names 8(2), 75-86. 1960.

Felecan, Oliviu. \& Bughesiu, Alina. (Eds.). Onomastics in Contemporary Public Space. (Cambridge: Cambridge Scholars Publishing. 2013).

Ferguson, Charles. A. Saints Names in American Lutheran Church Dedications. Names 14 no.2, (1966): 7682.

Guihang, Guo. \& Bingjie, LI. Linguistic Landscape of China: A Case Study of the Language use of Shop Signs in Wuhan. Studies in Literature and Language 15 no. 1, (2017): 1-9.

Hoffer, Bates. L. Language Borrowing and Language Diffusion: An Overview. Intercultural Communication Studies 11 no. 4, 2002: 1-37.

Hough, Carole. \& Izdebska, Daria. (Eds.). The Oxford Handbook of Names and Naming. (Oxford: Oxford University Press. 2016).

Koduah, Alfred. Christianity in Ghana today. (Accra: Advocate Publishing. 2004). 
Kouega, Jean. Paul. Language Management in "International" Pentecostal Churches in Cameroon. Open Access Library Journal 5 no.5, (2018): 1-15.

Kuwornu-Adjaottor, Jonathan. E. T. Mother-tongue Biblical Hermeneutics: A Current Trend in Biblical Studies in Ghana. Journal of Emerging Trends in Educational Research and Policy Studies 3 no.4, (2012): 575-579.

Labov, William. The Social Stratification of (r) in New York City Department Stores. (In Dialect and language Variation (pp. 304-329). Academic Press. 1986).

Lamb, M, A Matthew Effect of English Language Education in Developing Country Context. (In H Coleman (ed.). Dreams and Realities, Develop Countries and the English language (pp. 186-206). London: The British Council. 2011).

Noreen, Robert. G. Ghetto Worship: A Study of the Names of Chicago Storefront Churches. Names 13 no. 1, (1965): 19-38.

Obeng, Samuel. G. An Analysis of the Linguistic Situation in Ghana. African Languages and Cultures 10 no.1, (1997): 63-81.

Owu-Ewie, Charles. Language, Education and Linguistic Human Rights in Ghana. Legon Journal of the Humanities 28 no. 2, (2017): 151-172.

Pan, Hanting. The Immigration of Key Cultural Icons: A Case Study of Church Name Translation in Macao. (In. K. Malmkjær, A. Şerban and F. Louwagie (Eds.). Key Cultural Texts in Translation (pp. 140, 185). Amsterdam: John Benjamins Publishing Company. 2018).

Parkin, David. H. \& Parkin Harry. Surname typology and the problem of inconsistent classification. Names 61 no.4, (2013): 200-211.

Pearce, Thomas. M. Name Patterns in Aelfric's Catholic Homilies. Names 14 no.3, (1966):150-156.

Rogers, Burwell. P. Naming Protestant Churches in America. Names 11 no.1, (1963): 44-51.

Sawyer, John. Christianity in Europe. (In JFA Sawyer, JMY Simpson (eds). Concise Encyclopedia of Language and Religion, 33-35. Oxford: Elsevier. 2001).

Seaman, Mary. V. Name and Identity. Canadian Journal of Psychiatry 25 no.2, (1980): 129-137.

Stronks, James. B. Chicago Store-front Churches: 1964. Names 12 no.2, (1964):127-129.

Stronks, James. B. Names of Store-front Churches in Chicago. Names 10(3), (1962): 203-205.

Stronks, James. B. New Store-front Churches in Chicago. Names 11 no.2, (1963): 136.

Stump, Roger. W. Church-naming Practices among Eastern Rite Catholics in the United States Names: Journal of Onomastics 36 no.1-2, (1988): 85-90.

Stump, Roger. W. Pluralism in the American place-name cover: ethnic variations in Catholic Church names. North American Culture 2, (1986): 126-140.

Tent, Jan. \& Blair, David. Motivations for Naming: the Development of a Toponymic Typology for Australian Place Names. Names 59 no. 2, (2011): 67-89.

Tent, Jan. Indigenous Toponyms in the Antipodes: A Gazetteer-based study. Names 65 no.4, (2017): 204-214. Van Langendonck, Willy. Theory and Typology of Proper names (Vol. 168). (Berlin: Walter de Gruyter 2008). Yankson, Solace. A. Language Contact and Change in Linguistically Heterogeneous Urban Communities: The Case of Akan in Accra. (LOT: The Netherlands. 2018).

Yevudey, Elvis. \& Agbozo, Edzordzi. G. Teacher Trainee Sociolinguistic Backgrounds and Attitudes to language-in-education Policy in Ghana: A Preliminary Survey. Current Issues in Language Planning 20 no.4, (2019): 338-364.

Zeitler, Ezra. J. A Taxonomy of Secondary School Athletic Team names and Mascots in the United States. Names 66 no.4, (2018):219-232.

Zelinsky, Wilbur. The Names of Chicago's churches: A tale of at least two Cultures. Names 50 no.2, (2002): 83-103.

Zimmerman-Liu, Teresa. \& Wright, Teresa. What is in a Name? A Comparison of being branded a Religious Cult in the United States and the people's republic of China: Witness Lee and the Local Churches. Journal of Church and State 60 no.2, (2015): 187-207. 